\title{
EXCELLENCE CENTERS OF EDUCATION IN LATVIA
}

\author{
Kaspars Kiris \\ University of Latvia, Latvia
}

\begin{abstract}
The process of developing competence centres of vocational education and training is going on since 2009; they are planned to become centres of excellence. State gymnasiums can be such centres among schools of general education. The number of students in state gymnasiums compared to the number of students in other general educational establishments is totally different from the number of students in competence centres of vocational education and training compared to the number of students in other Vocational Education and Training (VET) establishments.

The aim of the work is to explain the principles of promoting excellence in Latvia, to give recommendations how to develop balanced excellence on the level of secondary education to ensure a united policy of excellence.

During the research the author:

- Compares the information about state gymnasiums and competence centres of VET,

- Explains the role of the establishments and the numbers' tendencies of students in them,

- Compares the amount of earmarked grants and their validity according to the requirements and the results of work.

Relying on the results of the analyses, the author draws a conclusion that in both - general educational level and in VET excellence is being developed. Though there are several similarities, there are substantial differences that must be taken into account while creating the future educational politics and educating the whole society.
\end{abstract}

Keywords: Vocational Education and Training, excellence, equity, general secondary education.

\section{ABBREVIATIONS USED IN THE WORK:}

GVEE - General Vocational Educational Establishment

SG - State Gymnasium

CCVET - Competence Centre of Vocational Education and Training 


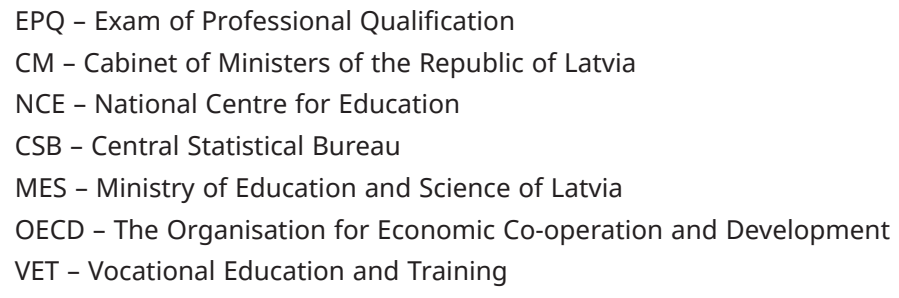

\section{Introduction}

Essential changes have taken place in the field of Vocational Education and Training of Latvia since 2009. The result is reorganising several educational establishments and the resources have been redirected to the development of the reorganised and capable to work establishments (Kiris, 2014).

The attractiveness of General Vocational Educational Establishment (GVEE) in the eyes of pedagogues was fostered by changes in the Cabinet of Ministers of the Republic of Latvia (CM) regulations regarding salary in GVEE that came into force in the autumn of 2016 (Latvia. Cabinet of Ministers, 2011). The change in the way how the salary is calculated improved the financial state of the pedagogues thus making these positions more attractive for new employees.

At the same time there have been changes in the VET of Latvia. And the managing institutions must take responsibility for them as well as follow how successfully they are implemented. Having reached the quantitative changes- increasing the number of students, it is necessary to turn to indicators of quality. One of them is excellence.

In the research paper problems connected to the excellence in Latvian secondary vocational education and training are being analysed.

The aim of the research is, analysing the situation, develop recommendations promoting excellence in the Latvian vocational education and training.

To reach the aim the author puts forward the following tasks:

- To find out the tendencies of development of educational excellence and educational equity in Latvia and in the world.

- To analyse normative documents for providing demands of excellence.

- To analyse the number of students in the educational establishments and the achievements in the field of excellence.

A thesis has been put forward in the work: State gymnasiums are the centres of excellence among the general educational establishments; they have their defined goals and financial support. The Vocational educational and training centres must constitute similar system of excellence matching the demands and support with State gymnasium system. 


\section{Excellence and Equity}

There are two opposed systems regarding educational quality. That is a tendency towards excellence and as opposed to it - progressing towards equity.

Excellence cannot be accidental; it must be planned (McMahon et al, 2015). Working towards massive excellence purposefully, the society must understand that excellence has its negative sides; it cannot please mediocrity and create comfort for the society (Rossouw, 2015).

The countries of the world that have pronounced progress towards excellence are Singapore, South Korea; educational excellence in literature must be defined precisely, but in the context of education it has subjective values and context (Brown, 2017).

The model offered by Joo promoting excellence in VET is demonstrating how industry cooperates with college through orders needed skills and technicians. Technical education for employees, regular classes for students, education for jobseekers and internationally - associated education makes a customized agreement that impacts industry and college as VET representing institution (Joo, 2017). There is a constant cooperation going on between the industry (customer) and the educational establishment (performer). As the result of cooperation there is transferring experiences from the employer to the educational establishment, a regular process of self-control and updating. The international education of employees, students, unemployed is a planned process, the accessibility of which improves educational excellence (Gunzelmann, 2009).

The approach suggested by Joo model is being used in Latvia in GVEE, it is stated in regulations issued by CM (Latvia. Cabinet of Ministers, 2013). The input of finances into vocational education, while improving technologies of education and accessibility (MES, 2018), is evidence of progress of educational excellence.

Characteristics of equity: socio-emotional comfort, confidence, education based on competences, the relative growth of a personality (Rossouw, 2015, Gourlay, Stevenson, 2017). Evident conditions of equity respect special needs of each side and put an accent on the relative growth, focusing on being aware of learning and analyses (Olina et al, 2018). Many authors object to the complicated multifactor concept "excellence", pointing out that it only looks accessible to everyone and it limits studies based on competences as well as social political needs of students (Gourlay, Stevenson, 2017)

In the USA, UK and Finland the needs for education of gifted students are not met purposefully, that is characteristics that shows a visible progress towards equity; competition is an essential part of the success of the society (Brown, 2017). 
OECD in its model of equity of educations, points out the most significant indicators that influence the socio economical well - being. The model demonstrates that 3 important factors stand out: cognitive achievements, the social emotional well- being and the educational attainment. In the spotlight there is a student and the approach directed by a student (OECD, 2018)

Speaking about GVEE in Latvia the movement towards education based on competences cannot be ignored. If students in the primary level will have acquired knowledge based on competences and practical work, GVEE would have to continue the same type of approach. That is a big step towards equity.

To acquire positive traits from directions of equity and excellence development, a synthesis of approaches is possible. Applying Friedrich Nietzsche's drastic point of view to the vocational education, opens a dimension of excellence to all students, offering "to excel yourself" not "be the best" (Joosten, 2015). It fosters relative excellence. It must be understood that the result of a synthesis like this means changing not only the way of studying but also the way of assessing. Each learner's individual growth must be evaluated, and the attitude must be changed thus improving the wish to develop and surpass oneself.

All level VET participants must develop towards both - excellence and equity: policy makers, vocational educational establishments and employers have to develop modern, timely, prestigious educational environment, the professional competence of the pedagogues must be improved but the students have to take responsibility of their own growth and the development of their career (Baranovska et al., 2015).

\section{Methodology}

To get a notion of excellence in the secondary education in Latvia, the author compared state gymnasiums (SG) and Competence Centres of Vocational Education and Training (CCVET) in the following categories: duties, support, the criteria of founding, and the quality indicators. The CM regulations have been analysed to clarify the demands set for founding an educational establishment, requiring or losing a special status of SG or CCVET. To define quantitative and qualitative achievements data of National Centre of Education (NCE) and Central Statistics Bureau (CSB) have been compared.

To compare the proportion of students admitted to schools and those who have dropped - out the relative calculation method has been used: inquiring about those dropouts that started studying respectively 3 years earlier in SG or 4 years earlier in CCVET. Such approach allows avoiding 
comparing non-objective data during one school year. Comparing like that can be misleading because the quotient of admitted students and dropouts is connected to demographical indicators.

To compare salary of SG and CCVET teachers, quotient of "normative learners" was considered. Basically one learner has quotient 1 . As some conditions may vary (for example, school urbanisation, type of school, lerners' teaching programme, subordination of appropriate ministery etc.) quotient may increase up to 3.49. This quotient is called "normative learner" for one person. Total income for school is calculated by MES according summarized normative learners to one rate of a pedagogue (according to regulation it varies).

\section{Results}

Having analysed the regulations of the Cabinet of Ministers on SG (Latvia. Cabinet of Ministers, 2001) and CCVET (Latvia. Cabinet of Ministers, 2013), the author draws a conclusion that the status of SG and CCVET is secured on the level of CM under guidance of MES (Ministry of Education and Science of Latvia).

The responsibilities given to both types of establishments do not differ essentially. They include participation in the policy making of educational field, the methodical support in the region, the development and publishing of teaching materials, participations in the excellence events of the corresponding field (educational olympiades, state and international competitions etc). The State grant for salary of pedagogues do not differ essentially. The methods of calculating depend on urbanisation for SG, does not depend on urbanisation for CCVET.

But evaluating the earmarked grant it must be understood that the number of normative learners to one rate of a pedagogue in SG is from 10 to 16 , while in CCVET 10.8 and the quotient 1.4 is used for each student in SG whilst in CCVET the quotient is 1.0 (Latvia. Cabinet of Ministers, 2011, 2016). The amount earmarked grant for status is not different. All pedagogues of SG and CCVET get 10\% higher salary (quotient 1.1).

More essential differences are observed in the quantitative indicators. Having analysed the demands of the number of students at schools, a conclusion can be drawn that quality of learning programmes is more important in SG (comparatively lower demands for the minimal number of students). At the same time the demands in CCVET are very high; paying the most attention to uniting schools and their branches. In an establishment like this- with branches- all programmes are excellent (financially supported) and higher quotients for the status acquired are used for all students. 
Evaluating the results of the quality it has been noted that in SG there are $17.5 \%$ of students from the whole number of secondary students and during the course of years they have qualified to reach a certain level in Mandatory Centralised Exams and have shown stable results. At the same time the students at CCVET comprise 82,7\% (Table 1) of the total number of students studying at general vocational educational establishments. Observing the distributional disbalance of students a conclusion can be made that the main criteria in the case of CCVET are the results of exams of professional qualification (EPQ). The demands of passing them (EPQ) are too low to qualify at CCVET. Analysing the results of EPQ (Figure 1) it can be seen that the results of the exam correspond to Normal distribution, but the graph is tending towards high achievments, that is an evidence of criteria that can be reached too easily to get good results in EPQ.

Taking grades " 7 " and higher, it can be calculated that in school year $2017 / 18$ grades over " 7 " were given to $75 \%$ of students the majority of which are from CCVET.

Table 1. The Proportion of Students in SG and CCVET Compared to Other Educational Establishments (Latvia. Central Statistical Bureau, 2019)

\begin{tabular}{|l|c|c|}
\hline \multicolumn{1}{|c|}{ Parameter } & $\begin{array}{c}\text { Number of } \\
\text { students }\end{array}$ & $\begin{array}{c}\text { Proportion } \\
\text { (\%) }\end{array}$ \\
\hline school year 2017/18 GVEE & 24947 & \\
\hline school year 2017/18 CCVET (included in GVEE) & 20632 & $\mathbf{8 2 . 7}$ \\
\hline $\begin{array}{l}\text { school year 2017/18 General education secondary } \\
\text { schools }\end{array}$ & 37179 & \\
\hline $\begin{array}{l}\text { school year 2017/18 SG (included in the secondary } \\
\text { schools) }\end{array}$ & 6500 & $\mathbf{1 7 . 5}$ \\
\hline
\end{tabular}

The results differ as regards the admitted students and those who have dropped out. The minimum dropout rate for 2020 set by EU is not less than 10\% (European Commission, 2010). The same criteria are applied to SG and CCVET. In the country on the whole secondary schools stay within the boundaries of $10 \%$ (Latvia. National Centre for Education, 2018). The Figure 2 demonstrates a situation where the potential number of students in GVEE would be maintained even adding the European Union stated $10 \%$ in 2020 but the number of students in last years' decreases directly proportionally to the growing number of dropouts. Which means that instead of trying to stay within the boundaries of $10 \%$ in a certain year - schools must not try to increase the number of admitted students. 
They must take supportive measures so that the right choice is made for choosing the profession thus preventing dropping out.

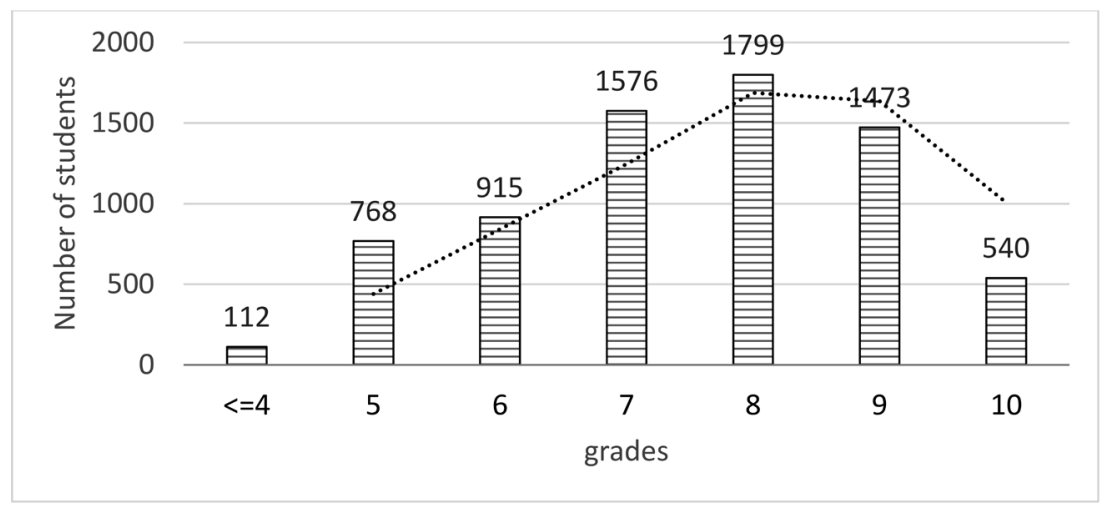

Figure 1. EPQ Results in the General Vocational Education

Establishments in School Year 2017/18

(Latvia. National Centre for Education, 2019)

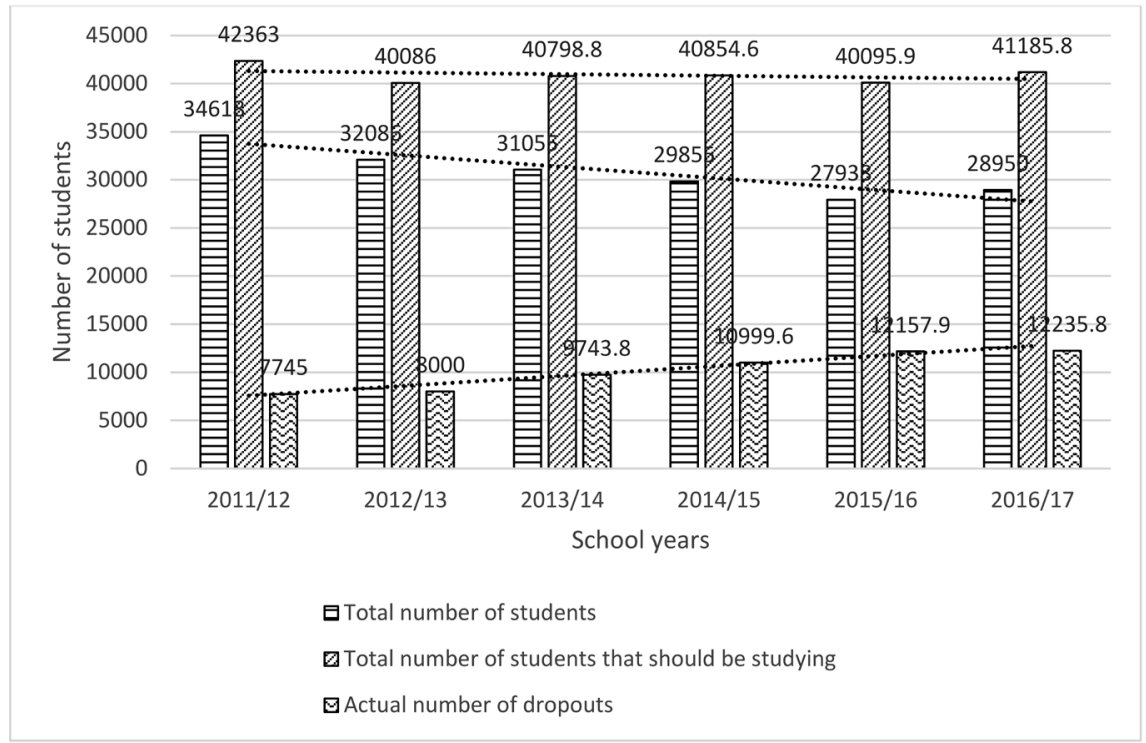

Figure 2. The Number of GVEE Dropouts

(Latvia. Central Statistical Bureau, 2019) 


\section{Conclusions}

A clear policy of developing excellence and equity dominates in the vocational education and training in the world. A synthesis of excellence and equity can be spotted in Latvia, a process of finding the most optimal proportion is going on. Excellence on the level of general education is granted to state gymnasiums. Excellence on the level of vocational training and education is given to Competence centres of vocational education and training. There are common tendencies but there is no united methodology to develop excellence in both directions.

$17 \%$ of general educational secondary school students study at state gymnasiums that are stable values and bases for the development of excellence at schools of general education.

$83 \%$ of students, study at CCVET; an overproduction of CCVET is observed; there is no competition among establishments that is a real driving force in the development of excellence.

There is a great number of dropouts in GVEE; the high results of admitting students are directly proportional to the number of students dropping out; at schools of general education, including SG, the number of dropouts is within the boundaries of the criteria set by EU for 2020 .

\section{Discussion}

The results demonstrate that on the whole Latvia wants to develop the dimension of excellence, but changes and corrections are necessary in the field of vocational education so stagnation does not set in. Regulations for founding CCVET must be renewed and corrected to decrease the number of students at CCVET to the $17 \%$ of students at state gymnasiums. In further researches the best way how to reach a quotient like that should be found.

It was found out that EPQ must be more complicated but doing it would not solve the problem of quality and excellence at CCVET. Perhaps the stress must be put on the indicator of excellence in the whole establishment. If the establishment provides programmes of various fields, it does not mean that it is excellent in all fields. Perhaps the number of CCVETs should be equalled to the number of industries, stating that the school can be a centre of excellence only in the field where excellence is gained, and it is one of a kind in the whole country.

To foster the indicators of excellence and improve the quality the criteria of decreasing the number of dropouts must be included in the model of forming salary in schools of Latvia. The assessment system in general must be changed, putting more accents on relative achievements of each student and evaluating student's and school's involvement in the 
achievements. A parallel work with families and students must be done increasing the understanding that each student must take responsibility about his/her own personal growth and ambitions. They must be aware of the investment of public resources in their education.

\section{References}

Baranovska I., et.al., (2015) VET to Work, 2015 http://www.lddk.lv/wp-content/ uploads/2015/06/VET-to-WORK_prev.pdf

Brown, E., F., \& Wishney, L., R. (2017). Equity and Excellence: Political forces in the education of gifted students in The United States and abroad. Global Education Review, 4(1). 22-33, Retrieved from: https://files.eric.ed.gov/fulltext/EJ1137995.pdf

European Commission, (2010) Communication From The Commission Europe 2020 A Strategy For Smart, Sustainable And Inclusive Growth. Revrieved from https://eur-lex. europa.eu/LexUriServ/LexUriServ.do?uri = COM:2010:2020:FIN:EN:PDF

Gourlay L, Stevenson J., (2017) Teaching excellence in higher education: critical perspectives, Teaching in Higher Education, 22:4, 391-395, DOI: 10.1080/13562517. 2017.1304632

Gunzelmann, B.,A., (2009) New Possibilities for a New Era: Research-based Education for Equality and Excellence, educational HORIZONS

Joo L., (2017) Vol. 1: The Excellence of Technical Vocational Education and Training (TVET) Institutions in Korea: Yeungjin College Case Study

Joosten H., (2015) Excellence for All: A Nietzschean-inspired approach in professional higher education, Educational Philosophy and Theory, 2015 Vol. 47, Nos. 13-14, 1516-1528, http://dx.doi.org/10.1080/00131857.2014.963491

Kiris, K. (2014) Development of the Centers of Vocational Education in Latvia, Society, Integration, Education 122.-123.

Latvia. Cabinet of Ministers, (2001) Regulation No. 129, G̦imnāzijas un valsts ğimnāzijas statusa piešķišanas un anulēšanas kārtība un kritēriji [Criteria and order to assign and cancel status of gymnasiums and State gymnasiums], Latvijas Vēstnesis, 48 (2435), 23.03.2001.

Latvia. Cabinet of Ministers, (2011) Regulation No. 523, Kārtība, kādā aprēkina un sadala valsts budžeta mērķdotāciju pedagogu darba samaksai pašvaldību izglītības iestādēs, kurās īsteno profesionālās pamatizglītības, arodizglītības un profesionālās vidējās izglītības programmas [About State grant for teachers' of Vocational Education and Training schools salary], Latvijas Vēstnesis, 105 (4503), 08.07.2011.

Latvia. Cabinet of Ministers, (2013) Regulation No. 144. Profesionālās izglītības kompetences centra statusa piešķiršanas un anulēšanas kārtība [Order to assign and cancel status of Competence Centres of Vocational Education and Training], Latvijas Vēstnesis, 58 (4864), 22.03.2013.

Latvia. Cabinet of Ministers, (2016) Regulation No. 447, Par valsts budžeta mērḳdotāciju pedagogu darba samaksai pašvaldību vispārējās izglītības iestādēs un valsts augstskolu vispārējās vidējās izglìtības iestādēs [About State grant for teachers' of compehensive schools salary], Latvijas Vēstnesis, 140 (5712), 22.07.2016.

Latvia. Central Bureau of Statistics (2019) Izglītojamo skaits vispārizglītojošajās dienas skolās pa klasēm [Number of students in comprehensive schools sorted by grades], 
Retrieved from http://data1.csb.gov.lv/pxweb/lv/sociala/sociala_izgl_vispskolas/ IZG090.px/

Latvia. Central Bureau of Statistics (2019) Profesionālās izglītības iestādes [VET schools], Retrieved from http://data1.csb.gov.lv/pxweb/lv/sociala/sociala_izgl_profesion/ IZG220.px/

Latvia. Ministery of Education and Science, (2018) Latvijā ES fondu investīcijas veido modernu izglìtības iestāžu infrastruktūru [Funds of European Union make modern infrastructure of educational intitutions], retrieved from: https://esfondi.lv/jaunumi/ izm:-latvija-es-fondu-investicijas-veido-modernu-izglitibas-iestazu-infrastrukturu

Latvia. National Centre for Education (2018) 2017./2018. m.g. profesionālās kvalifikācijas eksāmenu rezultātu kopsavilkums [Results of Professional Qualification Exams in school year 2017./2018.], retrieved from https://visc.gov.lv/profizglitiba/ eksameni/dokumenti/statistika/PKE_rezultati_2018.xls

Latvia. National Centre for Education (2018) Valsts pārbaudes darbi 2017./2018. m.g. [State exams in school year 2017./2018.], retrieved from https://visc.gov.lv/ vispizglitiba/eksameni/statistika/2018/dokumenti/!visi0_dati.xlsx

McMahon, A., Klopper, C., Power, B. (2015). Excellence in arts based education - One school's story. International Journal of Education \& the Arts, 16(5). Retrieved from http://www.ijea.org/v16n5/

OECD (2018), Equity in Education: Breaking Down Barriers to Social Mobility, PISA, OECD Publishing, Paris. Retrieved from https://doi.org/10.1787/9789264073234-en

Oliņa Z., Namsone D., France I., (2018), Kas ir mācīšanās iedziḷinoties jeb kādā procesā mācīšanās rezultāts var būt kompetence [What is deep learning or how learning result might become competence], LU SIIC retrieved from: https://doi.org/10.22364/ ml.2018.2

Rossouw JP, (2015) Quality, Social Justice And Accountability - Crucial Determinants Of Excellence In Education, Quality, Social Justice and Accountability in Education Worldwide. BCES Conference Books, Volume 13, Number 1 